Optical Coherence Straingraphy を用いた 平織り繊維強化ゴムにおけるマイクロメカニクスの断層可視化*

\author{
坂田義太朗*1, 佐 伯壮一*1 \\ 齊 藤 俊*1, 大 木 順 司*1
}

\title{
Tomographic Visualization on Micro Mechanics of Plain-Woven Fiber-Reinforced Rubber Using Optical Coherence Straingraphy
}

\author{
Yoshitaro SAKATA, Souichi SAEKI*2, \\ Takashi SAITO and Junji OHGI \\ *2 Applied Medical Engineering Science, Graduate School of Medicine, Yamaguchi University, \\ 2-16-1 Tokiwadai, Ube-shi, Yamaguchi, 755-8611 Japan
}

\begin{abstract}
It is well-known that woven fabric composite materials have high performance. It is, however, very difficult to access their mechanical behaviours due to their complexity of microstructual morphological geometry. Authors proposed Optical Coherence Straingraphy (OCS), which could visualize micro mechanical information tomographically and nondestructively from speckle deformation between synthetic images obtained by Optical Coherence Tomography. This is basically constructed by recursive cross-correlation technique and weighted moving least square method, which can offer cross-sectional strain distribution at the resolution of micrometer scale. In this study, applying OCS to plain-woven fiber-reinforced rubbers, the micro mechanical behaviour under uniaxial tensile load was visualized as an experimental strain distribution, which was verified by the numerical results based on image-based simulation. Consequently, tomographic strain distributions calculated by OCS agreed qualitatively with the simulated ones at the resolution of micro scale. It was, therefore, concluded that OCS could provide an experimentally powerful concept for the microstructual design of composite materials, as a nondestructive visualizing tool.
\end{abstract}

Key Words: Optical Coherence Straingraphy, Strain, Micro Mechanics, Composite Material, Plain-Woven Fiber-Reinforced Rubber, Optical Coherence Tomography, Nondestructive Imaging

\section{1. 緒論}

織物複合材料は, 強化材として繊維を織り構造の形 態で利用するため, 従来の積層型一方向強化複合材料 に比べ変形能や引裂強度に優れることから, 航空宇宙 機器を始め広範な分野で使用が進んでいる ${ }^{(1)}$. しかし, 幾何学的に複雑なマイクロ織り構造を有するため, 面 内単軸負荷に対しても面外変形や多軸応力がマイクロ スケールにて発生するため, 力学的評価が困難となる 問題点を抱えている. このため, 数值解析に基づく力 学特性評価が一般に行われており, 微視的な解析モデ ルとして不均質体モデル ${ }^{(2)(3)} や$ や均質化法 ${ }^{(4)}$ などが導入 され, 弾性特性の評価や初期損傷の予測などが報告さ れている. しかし, 実験的なマイクロメカニクスの非 破壊計測に関しては, 著者らの知る限り報告例が無く,

* 原稿受付 2009 年 12 月 21 日.

*1. 正員, 山口大学大学院医学系研究科応用医工学系専攻 (牢 755-8611 宇部市常盤台 2-16-1).

E-mail : s-saeki@yamaguchi-u.ac.jp
数值解析結果の検証も不十分と考えられる. 特に, 強 化材と母材との界面近傍における微視的な力学挙動は, 強度向上を目的としたマイクロ構造設計において不可 欠な検討課題であり ${ }^{(5)}$, 数值解析による予測に加えて 実験的なアプローチが強く望まれている.

一方, 医療診断機器の発達に伴い, 計測対象のマイク 口断層像を非破壊取得する手法である, 光コヒーレン 又断層画像法 (Optical Coherence Tomography; OCT) ${ }^{(6)}$ が開発された. OCT は近赤外広帯域光の低コヒーレ ンス干渉を利用し， $1 \sim 10 \mu \mathrm{m}$ の高空間分解能にて計 測対象内部からの散乱断層画像を得ることができる 計測法である. 著者ら ${ }^{(7)(8)}$ は, 計測対象内部のマイク ロスケール力学場検出法としてひずみ断層分布計測法 (Optical Coherence Straingraphy；OCS) を提案してい る.これは変形前後の OCT 断層画像にデジタル相互 相関処理を適用し，ひずみ分布を断層可視化する手法 である. 本研究では, 自動車用タイヤなどに用いられ る纎維強化複合材料の一種である平織り繊維強化ゴム 


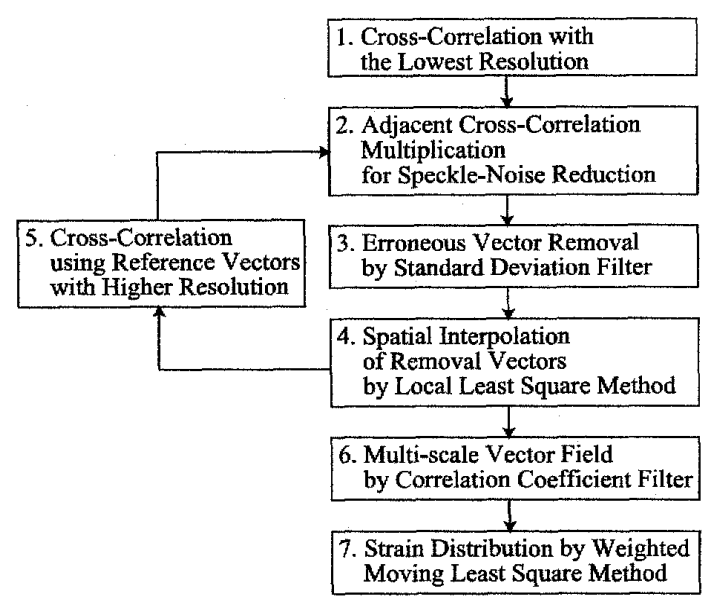

Fig. 1 Proposed OCS algorithm

に OCS 法を適用し，緎維と母材の界面近傍における マイクロメカニクスの断層可視化を行った. 有限要素 法による数值解析結果を用いて OCS 実験結果の検証 を実施し，複合秋料に対する非破壊検査法としての有 効性について報告を行う。

\section{Optical Coherence Straingraphy}

光コヒーレンス断層画像法 $(\mathrm{OCT}){ }^{(6)}$ は, 広帯域光の 低干渉性を利用した白色干涉法の一種である.一般に, 医療用途のため光ファイバーにより構築されたマイケ ルソン干渉計やマッハ・ツェンダー干渉計が用いられ ている．参照鏡の光軸方向走査と照射ビームの光軸垂 直方向走查により，計測対象の奥行き断層像を後方散 乱光の干涉光強度分布として取得する. 照射光光源に は, Super Luminescent Diode (SLD) などの近赤外広帯 域光源を用い，コヒーレンス長によって奥行き方向の 空間分解能 ${ }^{(6)}$ が決定される，一方，光軸垂值方向の分 解能 ${ }^{(6)}$ はビーム走查のため，対物レンズの N.A.に依 存したビームスポット径から決定される.これらをマ イクロスケールに設定することにより，被写界樑度内 における試料内部の形態情報を $1 \sim 10 \mu \mathrm{m}$ 程度の高空 間分解能にて取得可能となる. 奥行きダイナミックレ ンジは入射光に対応する各材料の光学特性により決定 する. 天然ゴムの場合， $1 \sim 2 \mathrm{~mm}$ 程度となる. 著者ら は, OCT 断層画像から力学特性分布を抽出する OCS 法を提案している(7)(8). 図 1 にそのアルゴリズムを示 す. OCS 法はデジタル相互相関法を基本としており, 計測対象変形前後の OCT 断層画像に適用し, 得られ た移動べクトル分布からひずみ分布を断層検出する手 法である．局所的なスペックル・パターンの類似度を 相関值 $R_{i, j}$ を用いて評価し，最大相関值を与える変位 量を変形前後の移動べクトル $\vec{U}_{i, j}$ として決定される. 本手法では，検査領域を縮小しながら相互相関処理を
繰り返し，空間解像度 (stage) を高める再帰的相互相関 法(7) (9)を採用している. 更に, スペックルノイズの影 響を受けたランダム性の強い相関值分布から正確な最 大相関値を決定するため, 隣接相互相関乗法 (Adjacent Cross-correlation Multiplication;ACM) ${ }^{(8)(10)}$ を導入して いる. なお, 最大相関値周りに2 次元 2 次多項式近似を 施し, 移動べクトル量をサブピクセル精度で算出して いる.ひずみ分布の算出には，重夕付き移動最小 2 乗 法 (Weighted Moving Least Square Method；WMLSM) (11)を採用している.これは，移動べクトル分布の各成 分に対し移動最小 2 乗法を用いて空間的に平滑化する と共に，微係数の安定算出を可能とする手法である. 局所的な検出精度を高めるため, ガウス関数 ${ }^{(11)}$ による 重み付け処理を行っている. 本実験では近似関数に 2 次元 2 次多項式を適用し, 最小 2 乗法に基づいて移動 ベクトル量の近似関数を決定すると共に，その微係数 をひずみテンソル各成分 $\varepsilon_{x x}, \varepsilon_{z z}, \gamma_{x z}$ として算出して いる. なお，検出移動ベクトル分布のベクトル数密度 はひずみ算出精度に影響するため，再帰的相互相関法 の各 stageにおいて最大相関值を䦭值として抽出した マルチスケールの移動べクトル分布 $\vec{U}_{m}\left(x_{k}, z_{k}\right)$ を用意 した．解析における設定などの詳細は，3.3 節及び前 報 ${ }^{(7)}{ }^{(8)}$ を参照して頂きたい.

\section{3. 実験}

3.1 実験装置 OCT システムと引張試験機によ り構成された OCS 実験装置を図 2 に示す. 本システム は, 高時間分解能と高位置検出精度を有する, 波長走査 型OCT システム (Swept-Source OCT;SS-OCT) ${ }^{(13)}$ を採 用している. SS-OCT は, 光源波長を高速走查して広帯 域光源を擬似的に実現すると共に, 取得される干涉ス ペクトル信号の逆FFT 処理により, 物体内部の奥行き 情報を取得するフーリエ領域型 OCT システムである. 光源に用いた波長走查型レーザ (HSL-2000, Santec) の 中心波長と波長掃引範囲は，それぞれ $\lambda_{c}=1330 \mathrm{~nm}$, $\Delta \lambda=110 \mathrm{~nm}$ であり, 光軸 $z$ 方向分解能は約 $6.9 \mu \mathrm{m}$ と なる. 対物レンズにはグラディウムレンズ $(f=60.0$ $\mathrm{mm})$ を用いており, 光軸垂直 $x$ 方向及び $y$ 方向の分解 能は約 $18 \mu \mathrm{m}$ となる. 一方, 高精度引張試験機 ${ }^{(14)}$ を用 い, 計測試料の固定及び変位付加を行った.これは高 精度りニアガイド・アクチュエータにより構成される試 験機で, 引張距離の分解能と繰り返し位置決め精度は それぞれ $1.0 \mu \mathrm{m}, \pm 1.0 \mu \mathrm{m}$ である. また, 荷重計測に はひずみゲージ式ロードセル (LVS-500GA，KYOWA, 定格容量 5.0N) を用い，動ひずみ測定器 (DPM-712B, KYOWA)にて堌幅取得している. なお, 分解能と精度 


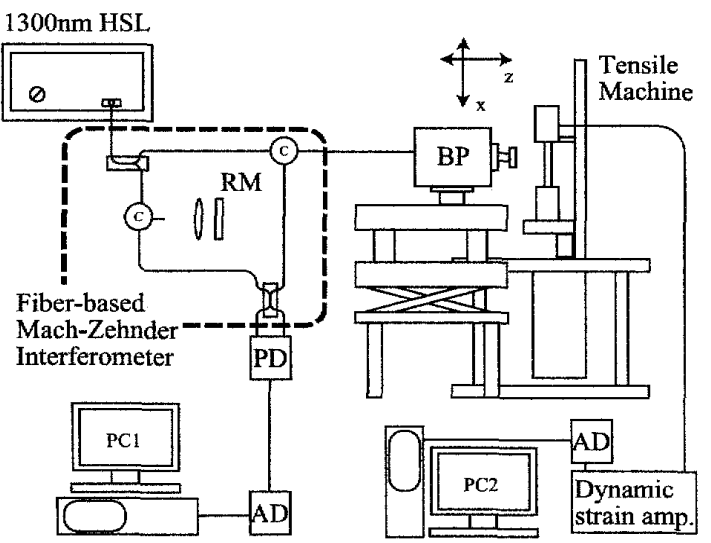

Fig. 2 Experimental OCS system; AD: A/D converter, PD: Auto-baranced photo detector, RM: Reference mirror, BP: Beam scanning probe

はそれぞれ $2.5 \mathrm{mN}, \pm 1.95 \mathrm{mN}$ である. 計測試料の材 料定数に関しては小型卓上引張試験機 (リトルセンス ター, JTトーシ, 定格容量 $1000 \mathrm{~N}$ ) を用いて計測した。

3.2 計測試料本研究で用いた試験片を図 3(a) に示す. 図 3(b) に示すナイロン 66 平織り瀻維 (レオナ LF940, 旭化成せんい, 縦 40 本/inch, 横 40 本/inch) を強化瀻維として用いており，図 3(c) のような3 次 元構造を有していることが確認できる. 母材としてイ ソプレンゴム (NIPOL-IR2200，日本ゼオン)を用いた が, OCT 断層計測への適用のため架橋材 パーへキサ 25B-40, 日本油脂) のみを使用し, 光透過性の制御を 行った. また, 強化瀻維と母材との接着を強化するた め, ゴム系接着剂を使用し加圧加熱製造により一層の 繊維強化ゴム (中国ゴム)を作成した，なお，この複合 材料の弾性係数は $E_{F R R}=58.11 \mathrm{MPa}$ であり, $20 \times 5 \mathrm{~mm}$ の大きさに切り出して実験に使用した. 複合材料内部 の構造を把握するため, 図 3(d)(e) に示す顕微鏡画像 によって試料断面を観察した. 緎維束と母材はそれぞ れ白色と灰色で撮影されており，上下の顕微鏡画像は 図3(c) に打ける断面 A(繊維束交差断面) と断面 B(緎 維束非交差断面)にそれぞれ詨応している. 図3(d)に 示す繊維束交差断面では, 緎維束 (経糸) が試料長手 方向に約 $1200 \mu \mathrm{m}$ の周期で蛇行しながら配向し，その 凹部に繊維束 (緯糸) が画像面外方向に配向している ことがわかる.一方, 図 3(e) に示す繊維束非交差断面 では, 繊維束 (緯糸) が画像面外方向に約 $600 \mu \mathrm{m}$ の間 隔で配向していることが確認できる. なお，図3(d)(e) の両図より接着剤が緎維束を覆うように硬化し, 繊維 と母材界面近傍に約 $50 \mu \mathrm{m}$ の接着層が存在しているこ とがわかる. 界面近傍から村にむけて黒色に変化し

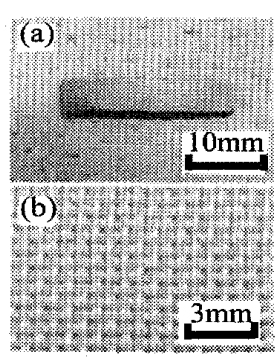

(c)

(d)

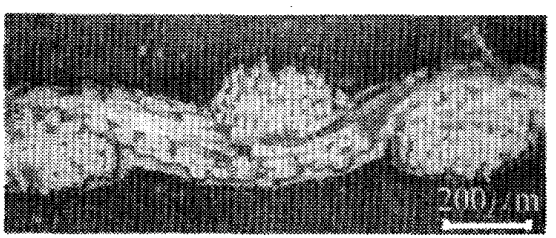

(e)
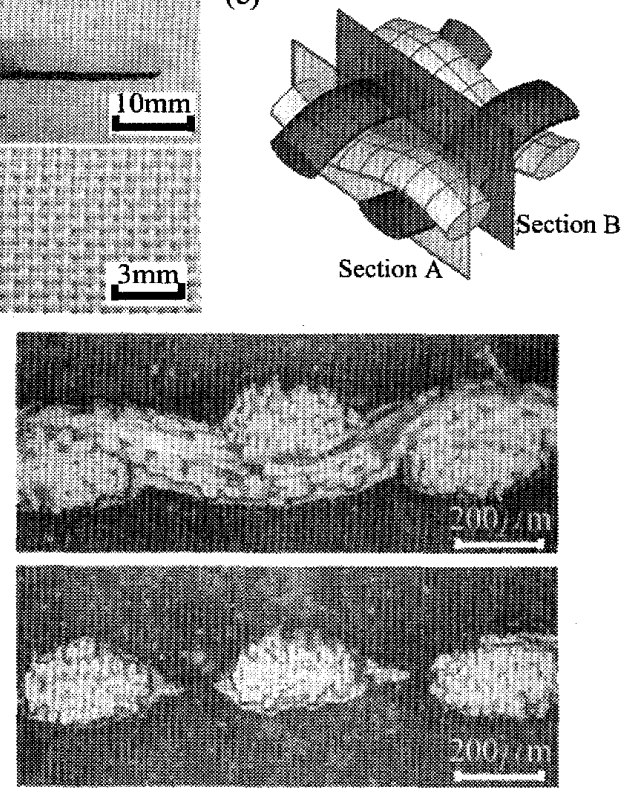

Fig. 3 Test material images of Fiber-reinfoced Rubber; (a) Top view, (b) Plain-woven Fabric Nylon, (c) 3-dimensional model of Plain-woven Fabric Nylon, (d) Cross-section $A$ at the intersection between warp and weft fiber bundles, (e) Cross-section B at the non-intersection

ていることから，接着剂が母材に $50 \sim 100 \mu \mathrm{m}$ 程度拡 散していることも確認できる.

$3 \cdot 3$ 実験方法 自作したアルミ製把持用ジグを用 いて計測試料を弓張試験機に固定した。 マイクロメー タを用いて $10 \mu \mathrm{m}$ 毎に引つ張りと緩和を繰り返し，荷 重応力が線形変化する位置を伸長ゼロ点位置とした. OCT 断層画像の撮影は，ガルバノミラーを用いて光軸 垂直 $x$ 方向及び $y$ 方向に $13.24 \mathrm{~mm}, 18 \mu \mathrm{m}$ の連続 2 次元 ビーム走榃を行い, $y$ 方向 $0.6 \mu \mathrm{m}$ 毎に 30 枚連続撮影し た. この断層画像に対し 3 枚毎にアンサンブル平均を施 し, 10 枚の $x z$ 断面の OCT 断層画像 $(1695 \times 384$ pixel $)$ を作成した。 なお，光軸 $z$ 方向分解能を考慮して両実 験とも画素サイズは $7.81 \times 7.81 \mu \mathrm{m} / \mathrm{pixel}$ と設定して いる. $10 \mu \mathrm{m}$ の引張変形前後の OCT 断層画像を撮影 し，OCS 法を適用した． 初期検查領域を $65 \times 65$ pixel と設定し, 最高解像度 (stage) が $15.6 \mu \mathrm{m}$ となるまで再 帰的相互相関処理を行った. 各解像度に対する相関值 の闇值 ${ }^{(12)}$ を経験的に $\kappa=0.58,0.60,0.67,0.89$ と設定 し，ひずみ分布算出に必要なマルチスケールの移動べ クトル分布 $\vec{U}_{m}\left(x_{k}, z_{k}\right)$ を作成した．これを 10 セットの OCT 断層画像から求め, 同一ベクトル場にプロット しWMLSM を適用してひずみ分布を検出した。 また, 計測試料表面や繊維束と母材の境界近傍などにおける 

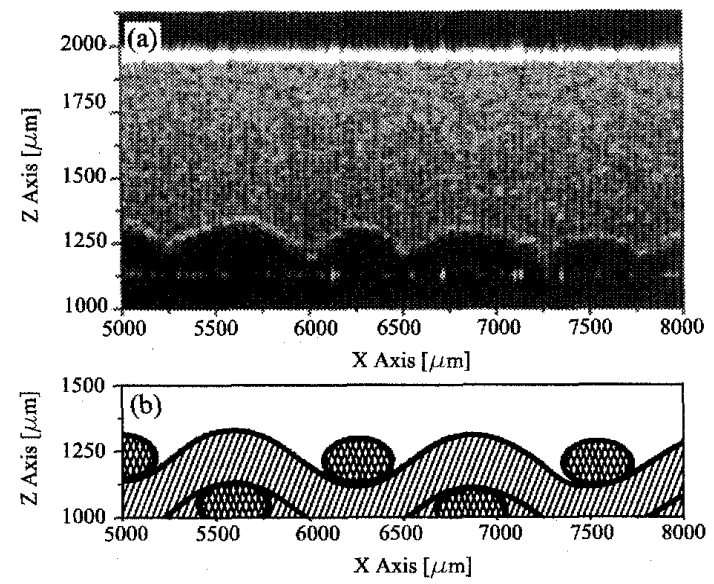

Fig. 4 2-dimensional image of Cross-section A; (a) OCT image, (b) Illustration of warp and weft fiber bundles,
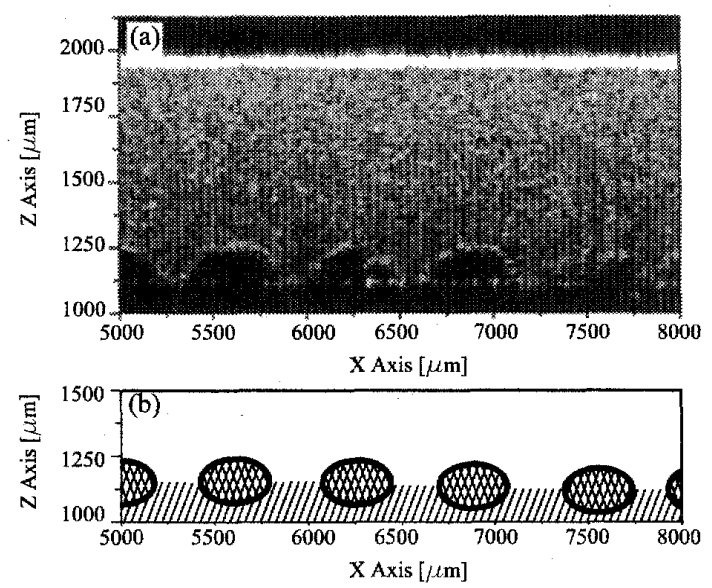

Fig. 5 2-dimensional image of Cross-section B; (a) OCT image, (b) Illustration of warp fiber bundles,

数值不安定を避けるため OCT 断層画像から試料境界 を抽出し，算出移動ベタトルを境界外に折り返す処理 を施した。

\section{4. 実 験 結 果}

4.12 次元形態断層分布図 3(c) に示す繊維束 交差断面 (断面 A) と繊維束非交差断面 (断面 B) に対 する OCT 断層画像を, 図 4(a) と図 5(a) に示す. OCT ビームは画像上方から照射され， $z=1900 \mu \mathrm{m}$ の位置 における高輝度な直線は試料表面を表し，それ以下の ランダムスペックルパターン $(z=1250 \sim 1900 \mu \mathrm{m})$ は, 母材 (イソプレンゴム) の散乱強度分布を表している. 母材下部の波状の形態は繊維束との界面を表している と考えられ, 繊維強化材を分離した母材のみを OCT 断層撮影したところ，ランダムスペックルパターンの
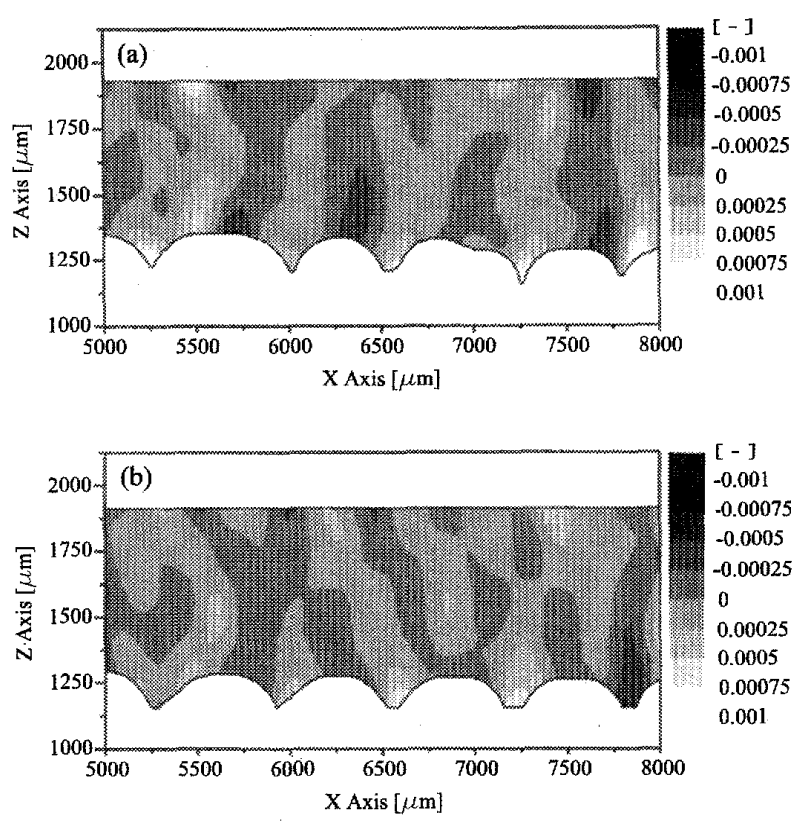

Fig. 6 2-dimensional stain distribution of $\varepsilon_{x x}$ obtained by $\operatorname{OCS}(\Delta x, \Delta z=15.6 \mu \mathrm{m}$ ); (a) Cross-section $A$ at the intersection between warp and weft fiber bundles, (b) Cross-section B at the nonintersection

領域が変化しないことを確認している，つまり，本試 料に用いたゴム系接着剤の光吸収特性と緎維束の散乱 減衰の影響のため, 繊維束は断層画像化できなかった と考えられる. 断面 A 及び断面 B における繊維束配 向の様子を図 4(b) と図 5(b) に示す. 図 4(b) では試料 長手方向に蛇行するように経糸が配向し，緯系が経糸 凹部に接触するように画像面外方向に配向しているの に対し, 図 5(b) では画像面外方向に緯系のみが配向 している。これは，両断面の OCT 断層画像 (闵 4(a), 図 5(a))に打ける下部波状曲線の形態と対応している ことが確諗できる. このように, OCT 断層画像によつ て繊維束の形態的特徴を非破壊検出可能である.

4.22 次元ひずみ断層分布 図 3(c) に示す断 面 A と断面 B に対する OCT 断層画像に OCS 法を 適用し, 算出された単軸引張 $x$ 方向ひずみ断層分布 $(\Delta x=31.25 \mu \mathrm{m}, \Delta z=30 \mu \mathrm{m})$ を図 6(a) と (b) に示す. なお，OCT 画像に打いて母材界面を表す高輝度曲線 を,ひずみ断層分布の表示限界として設定している. 図 6(a) に示す㵶維束交差断面から明らかなように, 経系 と緯系との接触点近傍において $+0.0003 \sim+0.0014[-]$ 程度の正のひずみの集中が検出された. 引張負荷によ り, 蛇行した繊維束 (経系) が直線化するように変形し たため，それに引き摺られるように母材も変形し，ひ ずみの集中が発生したと考えられる. 一方, 図6(b)に 
Table 1 Material parameters for isoprene rubber and fiber bundle used in numerical simulation

\begin{tabular}{lcc}
\hline Parameter & Nylon fiber bundle & Isoprene rubber \\
\hline$E_{1}$ & $4.7[\mathrm{GPa}]$ & $1.22[\mathrm{MPa}]$ \\
$E_{2}, E_{3}$ & $6.12[\mathrm{MPa}]$ & $1.22[\mathrm{MPa}]$ \\
$G$ & $4.89[\mathrm{MPa}]$ & $0.42[\mathrm{MPa}]$ \\
$v_{12}, v_{13}$ & 0.36 & 0.47 \\
$v_{23}$ & 0.00047 & 0.47 \\
\hline
\end{tabular}
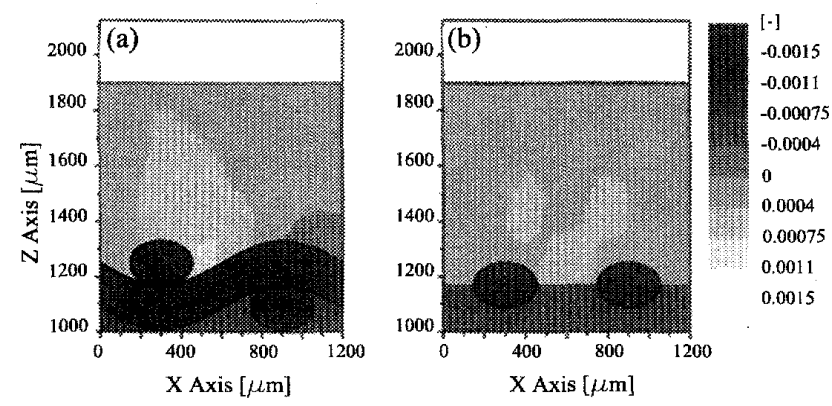

Fig. 7 2-dimensional stain distribution of $\varepsilon_{x x}$ obtained by FEM, (a) Cross-section $A$ at the intersection between warp and weft fiber bundles, (b) Crosssection $\mathrm{B}$ at the non-intersection

示す瀻維束非交差断面では隣接する瀻維束交差断面の 影響を受け，緯系間の母材にも +0.0001 +0.0007[-] 程度の正のひずみが検出されている.このように，緎 維束交差断面の方が非交差断面よりも 2 倍程度ひずみ が大きく検出されていることがわかる．以上の結果か ら, 繊維束接触点近傍における応力集中の発生予測が, 非破壊的に断層検出可能であると考えられる.

\section{5. 考察}

5.1 数值計算 OCS 法によって検出されたひず み断層分布の妥当性を検証するために，有限要素法に よる数值計算を実施し，各断面に発生するひずみ分布 の定性的な一致について考察を行った．図 3 に示す試 料断面画像を参考に 3 次元数值計算モデルを作成し た. 本モデルはUetsuji ら ${ }^{(15)}$ と同様に強化緎維束 (fiber bundle) と母材 (rubber) の 2 種類の材料から構成され る複合材料とし，簡略化のため接着層は無視している. 図 3 に示すように平織り繊維束は約 $1200 \mu \mathrm{m}$ の周期 で蛇行していることから，1 周期分を数值計算モデル とした。なお，繊維束断面形状は図 3(d)(e) を参考に， 長軸 $303 \mu \mathrm{m}$ ，短軸 $160 \mu \mathrm{m}$ の楕円とした．上記の平織 り繊維束を包含するように長さ $1200 \mu \mathrm{m}$, 幅 $1200 \mu \mathrm{m}$, 高さ $1460 \mu \mathrm{m}$ の領域に母材を設定した. 繊維束 (ナイ
ロン瀻維束)を直交異方性材料, 母材 (イソプレンゴ 厶) を等方性材料とそれぞれ定義し，表 1 に示す材料 定数を使用した. ナイロン䋐維束 $E_{1}$ 方向弾性係数は 製造元の提供值を利用し， $E_{2}, E_{3}$ 方向弾性係数は式 (1)を用いて算出した。

$$
\frac{1}{E_{i}}=\frac{V_{f}}{E_{f}}+\frac{1-V_{f}}{E_{m}}, i=2,3
$$

$E_{m}, E_{f}, V_{f}$ は，母材の弾性係数, 繊維束 $E_{1}$ 方向弾性 係数，緎維束繊維体積含有率を表している．なお，緎 維体積含有率 $V_{f}$ の算出のため, 図 3(d)(e) に示す顕微 鏡断面画像から緎維束内の任意領域を抽出し，2 值化 処理を施して䋐維領域面積を決定した。これを複数領 域にて算出し, その平均值から $V_{f}$ を求めた. せん断 弾性係数 $G$ は経験的に $E_{2}$ 方向弾性係数の $80 \%$ と設 定した. 一方，母材の弹性係数は単軸引張試験による 実測值を用いた。

上記の材料定数に従い, 汎用数值解析ソフト (ANSYS 12.0, ANSYS Inc.) を用いて有限要素解析を 行った. 本実験では計測試料 $10 \mathrm{~mm}$ に対して $3 \mu \mathrm{m}$ の 変形量,つまり $0.03 \%$ 程度のひずみが付加されたこと から, 本計算モデル $(1200 \mu \mathrm{m})$ に対して $0.36 \mu \mathrm{m}$ の変 位を片端に付加し，他端を完全固定として境界条件を 設定した. 要素形状は 3 次元 5 節点ソリッド要素を用 い,メモリの制約より要素サイズを $100 \mu \mathrm{m}$ と設定し た.ここで，マクロな弾性係数を用いて本数值計算モ デルの妥当性を検討した．本モデルの弾性係数を数值 計算したところ $64.87 \mathrm{MPa}$ となり，実駼結果と $10 \%$ 程 度異なることがわかった．本実験試料には接着剤が使 用されており，界面近傍において接着層の形成や母材 への拡散も確認された．このため界面近傍に扔いては 弾性係数の分布が発生していると考えられる。これに 対し，本数值計算では接着層を無視したモデルを採用 することに加え, 繊維束の蛇行に伴う繊維束内部の弾 性係数の分布も簡略化している. しかしながら本数值 計算では，OCS 法によって算出されるひずみ断層分布 との定性的な一致の検討を目的とするため，本モデル を用いた考察は可能であると考える.

5.2 検証結果 図7に示した数值計算結果は, 図 3 に示す繊維束交差断面 (断面 A) と絨維束非交差断面 (断面 B) における単軸引張 $x$ 方向ひずみ分布である. なお，網掛け部は OCT 断層画像では撮影できなかっ た領域を示している. 図7(a) から明らかなように，瀻 維束接触点近傍 $(x=500 \mu \mathrm{m}, z=1250 \mu \mathrm{m}$ 付近) に才 いて，局所的に $+0.001[-]$ 程度の正のひずみの集中が

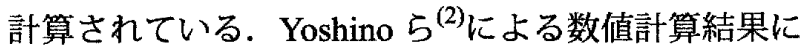


おいても，繊維束接触点近傍においてひずみの集中が 報告されていることから，本数值計算によっても同様 な結果が得られたと考える。一方，図 7(b) に示す繊 維束非交差断面では，隣接する交差断面の変形に影響 され緯糸間に $+0.0006[-]$ 程度の正のひずみが計算さ れ，その大きさは交差断面の半分程度であった.ここ で, 図 6 に示す OCS 実験結果と数值計算結果を比較 検証する．前述したように両者共に，繊維束交差断面 では繊維束接触点近傍において正の高ひずみが算出さ れ，繊維束非交差断面では交差断面の約半分のひずみ が検出されていることから，定性的な一致が確認でき る.なお，絾維束近傍のひずみ量の定量值について， 数值計算結果の方が 1.2 倍程度大きく算出されている が,これは上記した計算モデルと実験試料との整合性 の問題に加え，OCS 法が 2 次元ひずみを検出してい ることが影響していると考える.これらの検証結果よ りひずみパターンが定性的に一致することに加え， 各断面において異なるひずみ断層分布が検出されるこ とについても数值計算結果に追従する見解が得られた ことから, 纎維束と母材界面近傍でのマイクロメカニ クスを実験的かつ非破壊的に断層可視化可能であると 考える.

5.33 次元断層表示 複合材料内部の 3 次元的な 変形を観察するために，2 次元ひずみ断層分布を積層 化して 3 次元表示を行った. ガルバノミラーを用い光 軸垂直 $x$ 方向及び $y$ 方向それぞれに $2.1 \mathrm{~mm}$ の連続 2 次 元ビーム走查を行い, $y$ 方向 $10 \mu \mathrm{m}$ 毎に 210 枚の OCT 断層画像 $(269 \times 384 \mathrm{pixel})$ を連続撮影した.これを 5 回繰り返し撮影し，3 次元断層画像データを構築した. 3.3 節に記した設定と同様に, 引張変形前後に撮影した 3 次元 OCT 断層画像データに対して OCS 法を適用し, 検出された 2 次元ひずみ断層分布を積層化して擬似的 に3 次元可視化表示した. 図8(a)(b)k3 次元的な平織 り構造と 3 次元 OCT 計測から得られた平織り繊維束 の表面形状を示す．両図からわかるように， $x=450$, $1050,1650 \mu \mathrm{m}$ の位置において $y$ 方向に緯糸が蛇行し ながら配向しており，それらに交差するように $y=0$, $600 ， 1200 ， 1800 \mu \mathrm{m}$ の位置に経系も蛇行しながら配 向している. また, $y=300,900,1500 \mu \mathrm{m}$ の位置に 織維束非交差断面は存在している. 図 8(c) にx 方向ひ ずみ分布の 3 次元断層表示結果を示す. 引張負荷に伴 い, 織維束交差点近傍においてひずみが生じているこ とが確認できる. 図 8 に示す OCS 実験結果と数值計 算結果の両者に扔いて, $z=1230 \mu \mathrm{m}$ における $x$ 方向ひ ずみ断層分布 $(\Delta x=15.6 \mu \mathrm{m}, \Delta y=20 \mu \mathrm{m})$ を図 9 に示 す. 図中の網掛けは繊維束の平織り構造を示しており,
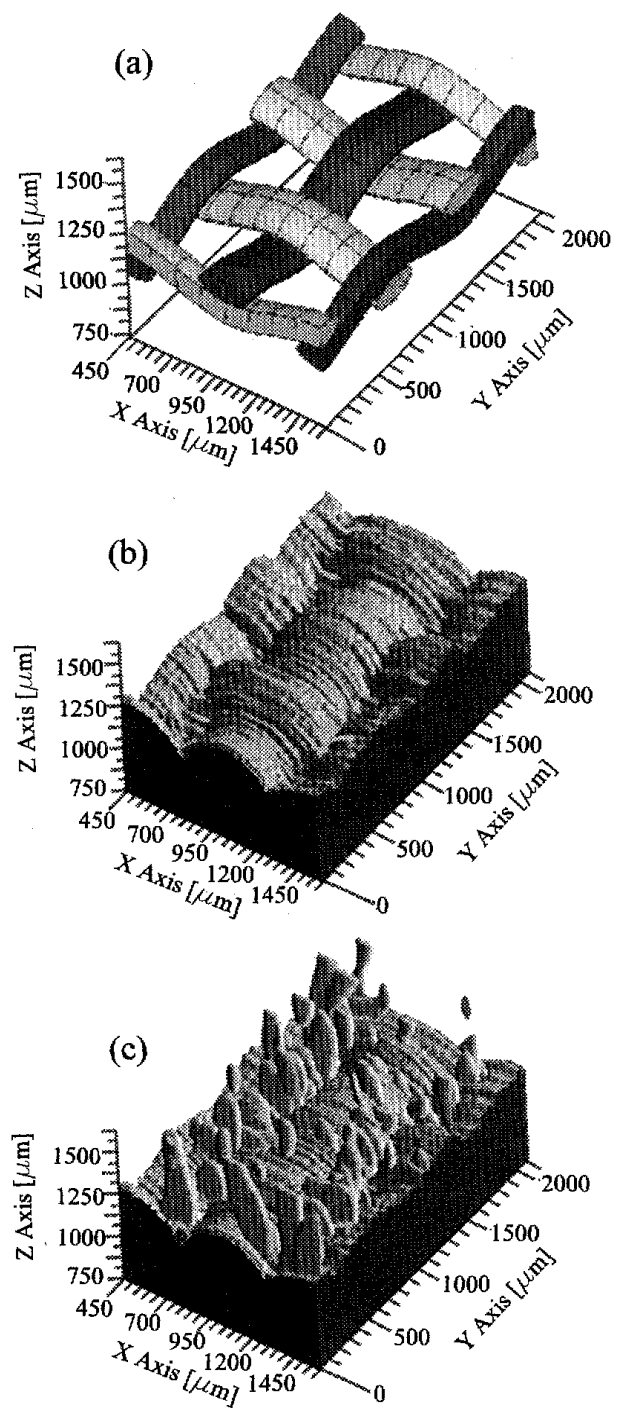

Fig. 8 3-dimensional images of FRR; (a) 3dimensional model of fiber bundles, (b) Surface configuration of fiber bundles obtained by OCT, (c) Stain distribution of $\varepsilon_{x x}$ obtained by OCS

灰色部は緎維束領域を表している．図 9(a) からわか るように, 繊維束接触点近傍 $(x=650 \mu \mathrm{m}, y=600 \mu \mathrm{m}$ 付近及び $x=750 \mu \mathrm{m}, y=1200 \mu \mathrm{m}$ 付近) に正の高ひ ずみ領域が OCS 法によって検出されていることが確 認できる. 一方, 数值計算結果においても瀻維束接触 点近傍 $(x=500 \mu \mathrm{m}, y=300 \mu \mathrm{m}$ 付近及び $x=700 \mu \mathrm{m}$, $x=900 \mu \mathrm{m}$ 付近) に正の高ひずみ領域が計算されてい る. 以上の結果より, $y$ 軸方向の計測分解能が低いた めひずみ分布にばらつきが観察されるものの，数值計 算結果と定性的に一致していることが理解できる。こ のように, 提案手法の 3 次元表示は 2 次元ひずみを積 層化した擬似的な 3 次元可視化法であるが，複合材料 

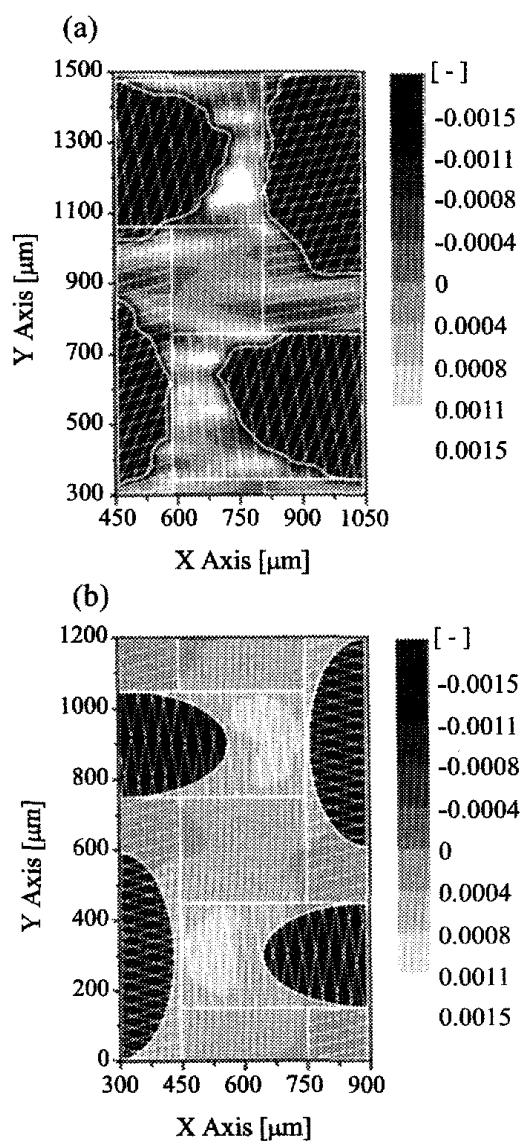

Fig. 9 Tomographic strain distribution of $x y$ crosssection at $z=1230 \mu \mathrm{m}$; (a) OCS result $(\Delta x=$ $15.6 \mu \mathrm{m}, \Delta y=20 \mu \mathrm{m})$, (b) Simulated result

内部のマイクロメカニクスを 3 次元的に断層可視化可 能であることから，その有効性を示唆できる.

複合材料では複雑な内部構造を有するため, マイク ロスケールにて局所的な力学場が特徴を持ち, これが マイクロスケールに影響を与える. そのため, マイク ロスコピックな領域で議論することが不可欠である. 実際に複合材料内部におけるマイクロメカニクスの重

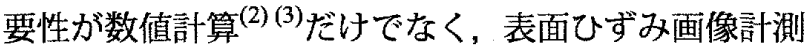
${ }^{(4)}$ によっても報告されている．材料内部の力学場を実 験的に検出する本手法は, 異種材料の界面近傍におけ る力学状態を断層可視化可能であり, 非破壊検查手法 としての有用性が明示された，プラスチックを母材と した複合材料においても，使用光波長帯と母材材料と の光学特性を考慮することによって，良好な OCT 断 層画像が撮影可能と考えられるため，本手法の応用可 能性も示唆できる.さらに，ナノテクノロジーの台頭 に伴う新素材開発に向けて，本手法によるマイクロメ カニクスの実験的解明は大きく貢献できると考える.

\section{6. 結言}

平織り綫維強化ゴムに OCS 法を適用し, 繊維強化 材と母材との界面近傍に打けるマイクロメカニクスの 実験的断層可視化を行った．検出された断層ひずみ分 布を数值計算結果と比較し，非破壊検査法としての有 效性について評価した. その結果，繊維束交差点近傍 に高ひずみ領域が両結果から検出され，ひずみ断層分 布は定性的に一致していることが確認された．以上の 結果から, OCS 法により複合材料内部における微小ひ ずみ断層分布をマイクロスケール空間分解能にて，非 破壊的に断層計測可能であることが示され，複合材料 の非破壊検査法として有効な実験可視化ツールとなる ことが示唆された。

本研究を行うに当たり, 山口大学大学院理工学研究 科の合田公一教授，野田淳二助教より助言を頂いた. ここに記して謝意を表す。

\section{文献}

(1) A. P. Mouritz, et al., Composites Part A: Applied Science and Manufacturing, Vol.30, No.12 (1999), pp.1445-1461.

(2) T. Yoshino, et al., Trans of Japan Society of Mechanical Engineers, Series A, Vol.59, No.566 (1993), pp.22972302.

(3) T. Yoshino, et al., Trans of Japan Society of Mechanical Engineers, Series A, Vol.60, No.573 (1994), pp.12601265.

(4) N. Takano, et al., Trans of Japan Society of Mechanical Engineers, Series A, Vol.61, No.585 (1995), pp.10381043.

(5) N. Takeda, et al., Journal of Society of Materials Science, Japan, Vol.49, No.4 (2000), pp.468-473.

(6) J. M. Schmitt, Journal of Selected Topics in Quantum Electronics, Vol.5, No.4, 1999, pp.1205-1215.

(7) S. Saeki, et al., Trans of Japan Society of Mechanical Engineers, Series A, Vol.72, No.720 (2006), pp.159-164.

(8) S. Saeki, et al., Trans of Japan Society of Mechanical Engineers, Series A, Vol.73, No.735 (2007), pp.94-101.

(9) D. P. Hart, Journal of Visualization, Vol.10 (1999), pp.110.

(10) D. P. Hart, Experiments in Fluids, Vol.29 (2000), pp.1322.

(11) T. Belytschko, et al., International Journal for Numerical Methods in Engineering, Vol.37 (1994), pp.229-256.

(12) S. Devasenathipathy, et al., Experiments in Fluids, Vol.34 (2003), pp.504-514.

(13) Y. Yasuno, et al., Optics Express, Vol.13, No.26 (2005), pp.10652-10664.

(14) K. Ichihara, et al., Journal of Neurosurgery: Spine, Vol.99 (2003), pp.278-285.

(15) Y. Uetsuji, et al., Journal of Society of Materials Science, Japan, Vol.48, No.9 (1999), pp.1029-1034. 